V. Molnár, Miskolc, Hungary

\title{
WEAR RESISTANCE OF HARD TURNED SURFACES
}

\begin{abstract}
The quality of working surfaces plays an important role in automotive industrial components. One of the main characteristics of such surfaces is their wear resistance. In this study external cylindrical surfaces were analyzed. A Design of Experiment methodology was applied and hard turning experiments were carried out to analyze the effects of the cutting parameters on the $3 D$ surface roughness values of reduced peak height, skewness and kurtosis. The study confirmed earlier findings that at lower feed the wear resistance is higher based on the analyzed roughness parameters. The cutting speed and the depth-of-cut do not influence these parameter values significantly.
\end{abstract}

Keywords: hard turning; wear resistance; $3 D$ surface roughness.

\section{INTRODUCTION}

A working surface means that it has motion relative to another surface. One of the most important phenomena in this relationship is the wear of surfaces. In the automotive industry many components incorporate working surfaces. Most of them have to be hardened in order to increase the wear resistance and therefore the life of the components $[1,2]$. Machining of these hard materials is challenging. Not only the conventional grinding but the use of single-point tools is also possible [3]. Hard turning is a good choice to machine hardened surfaces by a relatively high material removal rate and can result in an efficient procedure. However, turning hard materials requires a machine tool with rigid structure and superhard tool materials $[4,5]$ in order to reach the expected accuracy and surface quality [6]. Hard turning results in a periodic surface topography. If random topography is required, grinding is the recommended technology [7].

Due to the complex requirement system of working surfaces, topography and therefore surface roughness characterization have become highlighted topics in machining [8-10]. Wear resistance is of the tribological properties of surfaces. There are numerous roughness parameters that aim to provide information about the wear resistance of a surface, for example the peak height $\left(S_{p}\right)$, reduced peak height $\left(S_{\mathrm{pk}}\right)$, peak material portion $\left(\mathrm{S}_{\mathrm{r} 1}\right)$, peak material volume $\left(\mathrm{V}_{\mathrm{mp}}\right)$, skewness $\left(\mathrm{S}_{\mathrm{sk}}\right)$, kurtosis $\left(\mathrm{S}_{\mathrm{ku}}\right)$, and surface bearing index $\left(\mathrm{S}_{\mathrm{bi}}\right)$. These parameters are defined in different ways, for example $S_{\mathrm{sk}}$ and $S_{\mathrm{sk}}$ are dimensionless parameters, $V_{\mathrm{mp}}$ measures specific volume and $S_{\mathrm{pk}}$ measures a certain part of the profile height. These differences make comparison difficult. In one study it was stated that the orders of wear resistance of surfaces machined by different technological data are different in the cases of the differently defined roughness parameters [11]. 
In this study the results of hard turning experiments are demonstrated. The technological data (cutting speed, feed, depth-of-cut) were varied. According to the tool manufacturer's recommendation the lowest and the highest values of these data were applied and a design of experiment (DoE) was carried out, which resulted in 8 setups. Among the above mentioned parameters the relatively widely used $S_{\mathrm{pk}}$ and two statistical-based parameters, $S_{\mathrm{sk}}$ and $\mathrm{S}_{\mathrm{ku}}$, were analyzed. It has to be noted that the industrial use of the $3 \mathrm{D}$ roughness parameters is not widespread yet because of the relatively high time consumption; however, the accuracy of these parameters is considered better than that of their 2D counterparts [12-14].

The novelty of the experiments is that more than one roughness parameter was considered at the same time for the analysis of wear resistance and the experiments were designed for the total range of technological parameters. The results can provide useful information for the research of the tribological characteristics of machined surfaces.

\section{EXPERIMENTAL SETUP}

In the experiments external cylindrical surfaces were machined by hard turning. The technological data of the machining are summarized in Table 1, which also details the DoE setups.

Table 1 - Setups of the experiment and the applied technological data

\begin{tabular}{|c|c|c|c|}
\hline Surface / Setup & $\begin{array}{c}\text { depth-of-cut } \\
\mathrm{ap}_{\mathrm{p}}[\mathrm{mm}]\end{array}$ & $\begin{array}{c}\text { cutting speed } \\
\mathrm{v}_{\mathrm{c}}[\mathrm{m} / \mathrm{min}]\end{array}$ & $\begin{array}{c}\text { feed } \\
\mathrm{f}[\mathrm{mm} / \mathrm{rev}]\end{array}$ \\
\hline A & 0.05 & 60 & 0.05 \\
\hline B & 0.05 & 60 & 0.2 \\
\hline C & 0.05 & 150 & 0.05 \\
\hline D & 0.05 & 150 & 0.2 \\
\hline E & 0.3 & 60 & 0.05 \\
\hline F & 0.3 & 60 & 0.2 \\
\hline G & 0.3 & 150 & 0.05 \\
\hline H & 0.3 & 150 & 0.2 \\
\hline
\end{tabular}

The machining experiments were carried out on a CNC lathe type Optiturn S 600. In the machining experiment a Mitsubishi CNGA 120408TA4 type insert was used. The workpiece material was $16 \mathrm{MnCr} 5$, its hardness was $63 \mathrm{HRC}$. The lengths of the machined surfaces were $40 \mathrm{~mm}$ and their diameters were $70 \mathrm{~mm}$. 
The surface topography was analyzed by $3 \mathrm{D}$ roughness parameters. In the measurements $2.05 \times 2.05 \mathrm{~mm}$ areas were scanned by using a measurement machine type Altisurf 520. A $0.8 \mathrm{~mm}$ cut-off and Gauss filter were applied. The scanning was carried out using an optical sensor (type CL2). The $\mathrm{x}$ - and y-direction resolutions were $2 \mu \mathrm{m}$, therefore one million points were scanned. The $\mathrm{z}$-direction resolution was $0.012 \mu \mathrm{m}$. The nominal measurement range was $0-300 \mu \mathrm{m}$. For the analysis of the roughness parameters the standard ISO 25178 was used

\section{DISCUSSION}

The arithmetical mean heights $\left(\mathrm{S}_{\mathrm{a}}\right)$ were analyzed to get information about the surfaces based on a parameter which is widely used in industry. $S_{a}$ values vary between 0.11 and $1.08 \mu \mathrm{m}$. The machine tool proved to be good; no resonances were experienced during the machining process. In Fig.1 examples are demonstrated for the analyzed surfaces. In Table 2 the analyzed roughness parameter values are summarized for the 8 setups.

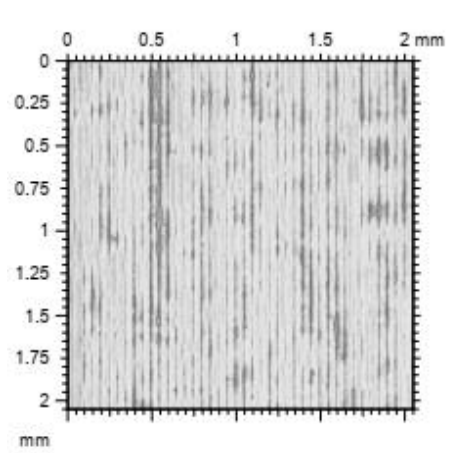

a

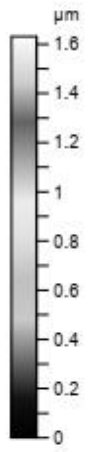

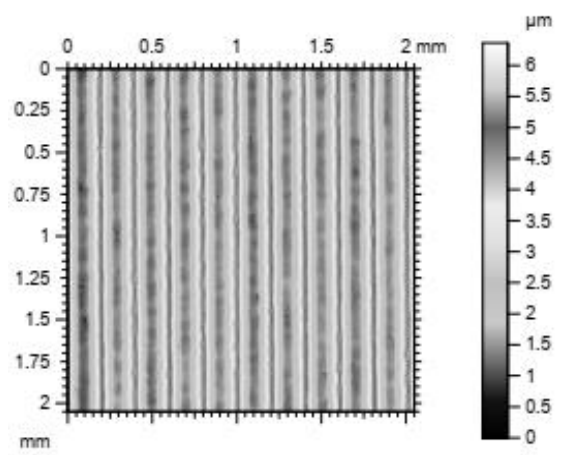

b

Figure 1 - Examples for hard turned topographies; (a) setup A, $a_{p}=0.05 \mathrm{~mm}, \mathrm{v}_{\mathrm{c}}=60 \mathrm{~m} / \mathrm{min}$, $\mathrm{f}=0.05 \mathrm{~mm} / \mathrm{rev}$, (b) setup $F, a_{p}=0.3 \mathrm{~mm}, v_{c}=60 \mathrm{~m} / \mathrm{min}, \mathrm{f}=0.3 \mathrm{~mm} / \mathrm{rev}$

The reduced peak height is defined according to Fig. 2. A lower value indicates better wear resistance. In Fig. 3 the values of this parameter are demonstrated. It can be observed that the feed influences this value to a relatively high extent. At $0.05 \mathrm{~mm}$ depth-of-cut (d-o-c), by increasing the feed from 0.05 to $0.2 \mathrm{~mm} / \mathrm{rev}$ the $S_{\mathrm{pk}}$ values are 11 and 9 times higher at cutting speeds of 60 and $150 \mathrm{~m} / \mathrm{min}$, respectively. At $0.3 \mathrm{~mm}$ d-o-c, by increasing the feed from 0.05 to 0.2 $\mathrm{mm} / \mathrm{rev}$ the $S_{\mathrm{pk}}$ values are 7 and 19 times higher at cutting speeds of 60 and $150 \mathrm{~m} / \mathrm{min}$, respectively. The lower feed results in better $S_{\mathrm{pk}}$ values. The depth-of- 
cut does not influence the value. It is not obvious how the cutting speed influences the parameter values. In the case of higher $d$-o-c $S_{\mathrm{pk}}$ increases with the cutting speed when higher feed is applied but in the case of lower d-o-c the opposite can be observed.

Table 2 - Measured roughness values

\begin{tabular}{|c|c|c|c|c|}
\hline Surface / Setup & $\mathrm{S}_{\mathrm{a}}$ & $\mathrm{S}_{\mathrm{pk}}$ & $\mathrm{S}_{\mathrm{sk}}$ & $\mathrm{S}_{\mathrm{ku}}$ \\
\hline $\mathrm{A}$ & 0.12 & 0.14 & -0.03 & 3.14 \\
\hline $\mathrm{B}$ & 0.94 & 1.56 & 0.65 & 2.39 \\
\hline $\mathrm{C}$ & 0.13 & 0.11 & -0.26 & 3.20 \\
\hline $\mathrm{D}$ & 0.65 & 1.09 & 0.59 & 2.10 \\
\hline $\mathrm{E}$ & 0.21 & 0.21 & 0.05 & 2.64 \\
\hline $\mathrm{F}$ & 1.04 & 1.53 & 0.54 & 2.11 \\
\hline $\mathrm{G}$ & 0.11 & 0.10 & -0.20 & 3.13 \\
\hline $\mathrm{H}$ & 1.08 & 1.88 & 0.62 & 2.21 \\
\hline
\end{tabular}

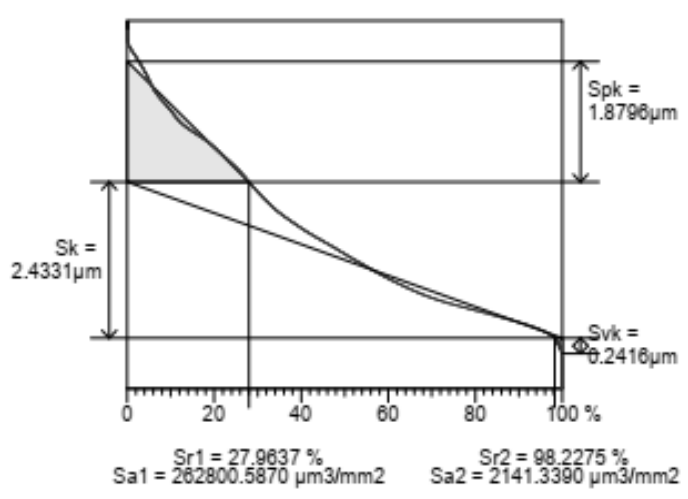

Figure 2 - Calculation of the Spk parameter (setup H)

In Fig. 4 the value ranges for the $2 \mathrm{D} \mathrm{R}_{\mathrm{sk}}$ and $\mathrm{R}_{\mathrm{ku}}$ parameters are demonstrated for easier visualization.

The skewness gives information about the wear resistance, among other things. A negative or zero value belongs to a greater bearing area, therefore the wear resistance is better. In all the experimental setups the values do not exceed 0.7 (Fig. 5). When lower feed was applied, the values were around or below zero. The 
reason for this is that by such low feed the tool 'burnishes' the surface. At $0.05 \mathrm{~mm}$ d-o-c, by increasing the feed from 0.05 to $0.2 \mathrm{~mm} / \mathrm{rev}$ the $S_{\mathrm{sk}}$ values increase by 0.68 and by 0.85 at cutting speeds of 60 and $150 \mathrm{~m} / \mathrm{min}$, respectively. At $0.3 \mathrm{~mm}$ d-o-c, by increasing the feed from 0.05 to $0.2 \mathrm{~mm} / \mathrm{rev}$ the $\mathrm{S}_{\mathrm{sk}}$ values increase by 0.51 and by 0.82 at cutting speeds of 60 and $150 \mathrm{~m} / \mathrm{min}$, respectively.

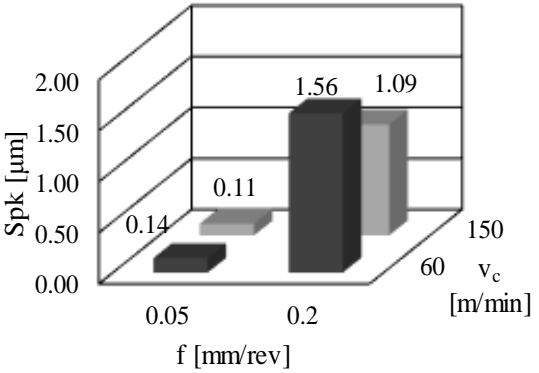

$\mathbf{a}$

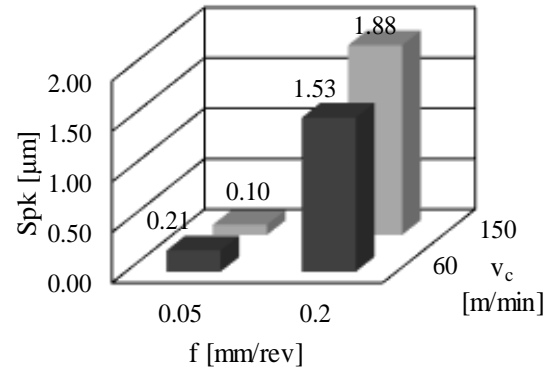

b

Figure 3 - Reduced peak height: (a) $a_{p}=0.05 \mathrm{~mm}$, (b) $a_{p}=0.3 \mathrm{~mm}$
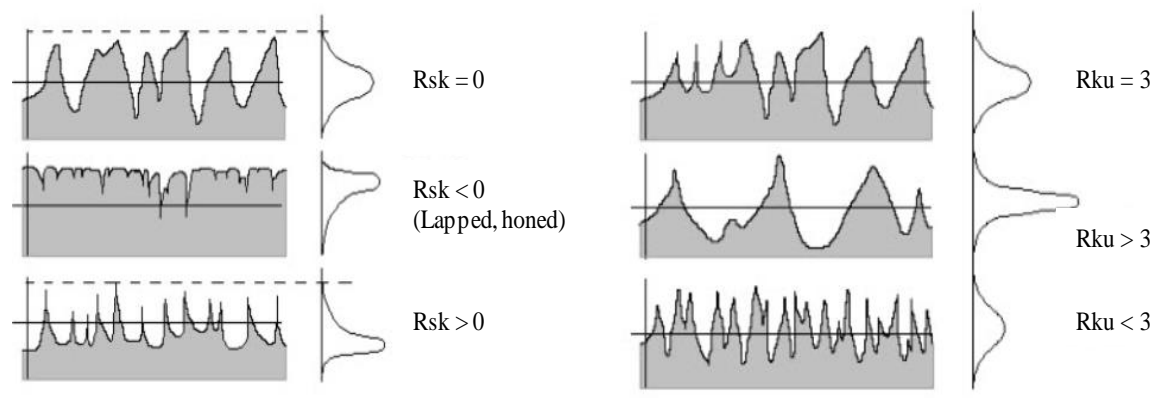

Figure 4 - The values of Rsk and Ssk parameters [15]

If the kurtosis value is 3 or lower, the wear resistance increases. When a lower feed was applied, the values were around 3. At higher feed the values decreased. At $0.05 \mathrm{~mm} \mathrm{d-o-c,} \mathrm{by} \mathrm{increasing} \mathrm{the} \mathrm{feed} \mathrm{from} 0.05$ to $0.2 \mathrm{~mm} / \mathrm{rev}$ the $S_{\mathrm{ku}}$ values decrease by 0.75 and by 1.10 at cutting speeds of 60 and $150 \mathrm{~m} / \mathrm{min}$, respectively. At $0.3 \mathrm{~mm} \mathrm{~d}-\mathrm{o}-\mathrm{c}$, by increasing the feed from 0.05 to $0.2 \mathrm{~mm} / \mathrm{rev}$ the $S_{\mathrm{ku}}$ values decrease by 0.53 and by 0.92 at cutting speeds of 60 and $150 \mathrm{~m} / \mathrm{min}$, 
respectively. The d-o-c has no significant influence on the $S_{\mathrm{ku}}$ value. The role of the cutting speed is again not obvious.

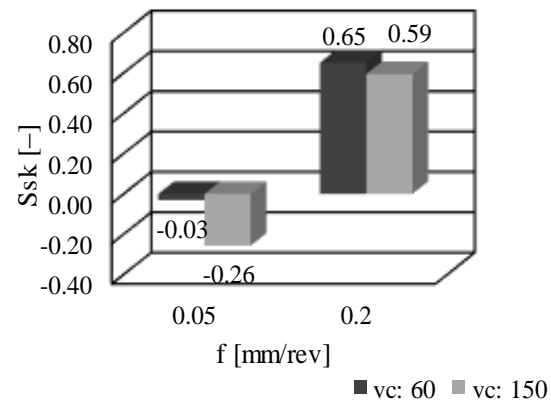

a

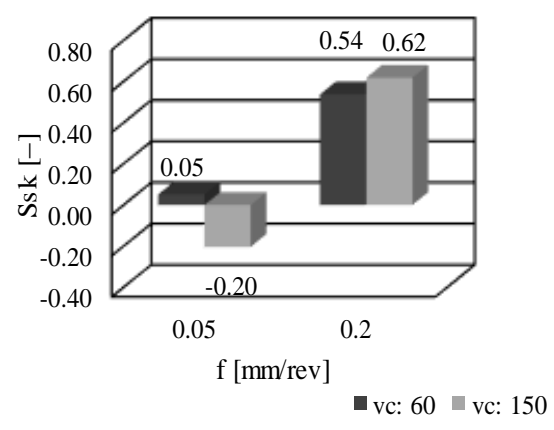

b

Figure 5 - Skewness values: (a) $\mathrm{a}_{\mathrm{p}}=0.05 \mathrm{~mm}$, (b) $\mathrm{a}_{\mathrm{p}}=0.3 \mathrm{~mm}$

Analyzing the three roughness parameters the following order can be stated among the setups (better wear-resistance from left to the right):

- $\mathrm{S}_{\mathrm{pk}}: \mathrm{H} \rightarrow \mathrm{B} \rightarrow \mathrm{F} \rightarrow \mathrm{D} \rightarrow \mathrm{E} \rightarrow \mathrm{A} \rightarrow \mathrm{C} \rightarrow \mathrm{G}$

- $\mathrm{S}_{\mathrm{sk}}: \mathrm{B} \rightarrow \mathrm{H} \rightarrow \mathrm{D} \rightarrow \mathrm{F} \rightarrow \mathrm{E} \rightarrow \mathrm{A} \rightarrow \mathrm{G} \rightarrow \mathrm{C}$

- $\mathrm{S}_{\mathrm{ku}}: \mathrm{D} \rightarrow \mathrm{F} \rightarrow \mathrm{H} \rightarrow \mathrm{B} \rightarrow \mathrm{E} \rightarrow \mathrm{C} \rightarrow \mathrm{A} \rightarrow \mathrm{G}$

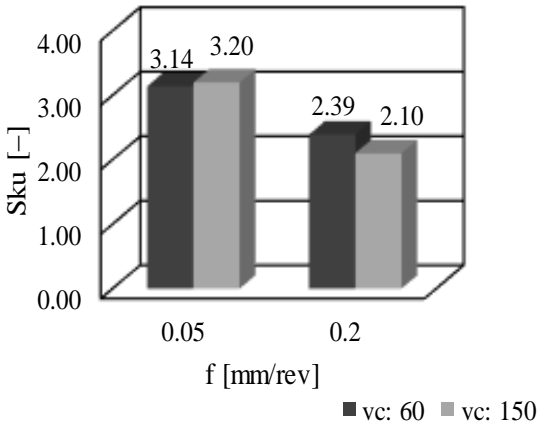

a

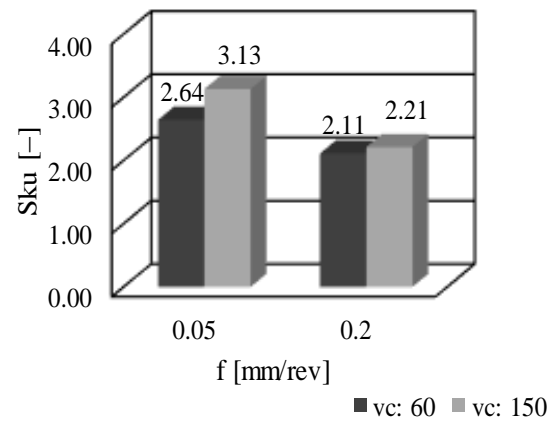

b

Figure 6 - Kurtosis values: (a) $\mathrm{a}_{\mathrm{p}}=0.05 \mathrm{~mm}, \mathrm{~b}$ ) $\mathrm{a}_{\mathrm{p}}=0.3 \mathrm{~mm}$ 


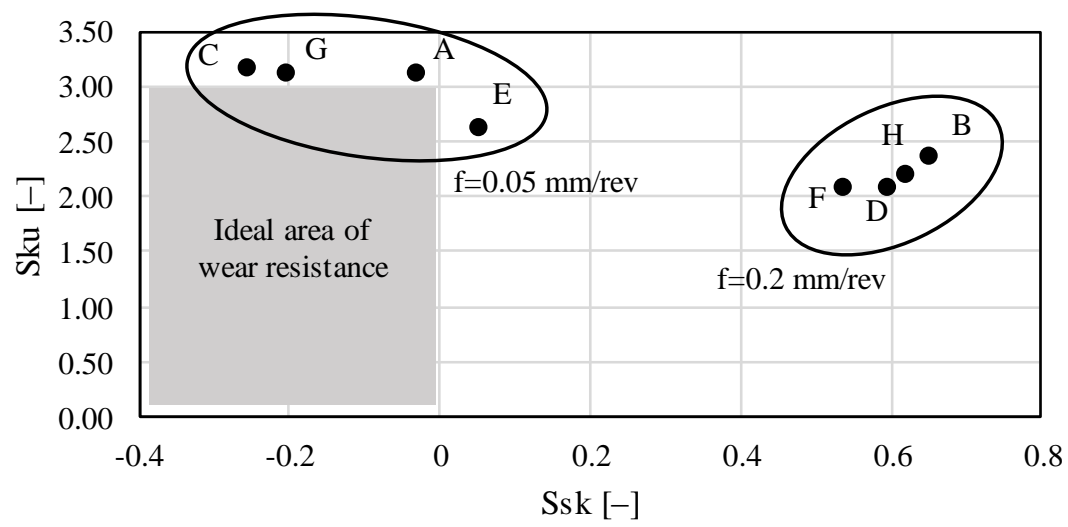

Figure 7 - Tribological topography map

The second four setups belong to the feed $0.05 \mathrm{~mm} / \mathrm{rev}$ in all the three cases. The reason for this clear order is that because of the lower feed a relatively 'filled' topography is formed by the cutting tool. Concerning the other two technological parameters no clear tendency can be identified. It has to be noted that the surface topography is mainly determined by the feed. This can be seen also in Fig. 7.

\section{CONCLUSIONS}

Hard turning experiments were carried out for 8 setups by varying the technological parameter values of the cutting speed, the depth-of-cut and the feed. $\mathrm{S}_{\mathrm{pk}}, \mathrm{S}_{\mathrm{sk}}$ and $\mathrm{S}_{\mathrm{ku}} 3 \mathrm{D}$ surface roughness parameters were analyzed. The change of the d-o-c and the cutting speed do not influence the analyzed values. The only clear statement of the experiments is that the feed influences the analyzed roughness parameters. When lower feed $(0.05 \mathrm{~mm} / \mathrm{rev})$ was applied, the wear resistance was clearly better than in the case of higher $(0.3 \mathrm{~m} / \mathrm{rev})$ feed. All the three roughness parameters support this statement.

References: 1. Linins, O., Krizbergs, J., Boiko, I.: Surface texture metrology gives a better understanding of the surface in its functional state, Key. Eng. Mater., No.527, 2013, pp.167-172, DOI: 10.1016/j.precisioneng.2016.06.001. 2. Karpuschewski, B., Kundrak, J., Emmer, T., Borysenko, D.: A new strategy in face milling-inverse cutting technology, Solid State Phen., No. 261, 2017, pp.331-338. 3. Grzesik, W., Rech, J., Zak, K.: High-precision finishing hard steel surfaces using cutting, abrasive and burnishing operations, Procedia Manuf., No.1, 2015, pp. 619-627, DOI: 10.1016/j.promfg.2015.09.048. 4. Zawada-Tomkiewicz, A.: Analysis of surface roughness parameters achieved by hard turning with the use of PCBN tools, Estonian J. Eng., No.17, 2011, DOI: 10.3176/eng.2011.1.09. 5. Kundrak, J., Nagy, A., Markopoulos, A.P., Karkalos, N.E.: Investigation of surface roughness on face milled parts with round insert in planes parallel to the feed at various cutting speeds, Cut. Tools Technol. Syst., 2019, pp.87-96, DOI: 10.20998/2078-7405.2019.91.09. 6. Mamalis, A.G., Kundrak, J. Horvath M: On a 
novel tool life relation for precision cutting tools, J. Manuf. Sci. Eng., No.127, 2005, pp.328-332, DOI: 10.1115/1.1794158. 7. Grzesik, W., Zak, K., Kiszka, P.: Comparison of surface textures generated in hard turning and grinding operations, Procedia CIRP, No.13, 2014, pp.84-89, DOI: 10.1016/j.procir.2014.04.015. 8. Blawucki, S., Zaleski, K.: The effect of the aluminium alloy surface roughness on the restitution coefficient, Adv. Sci. Technol. Res. J, No.9, 2015, pp.66-71, DOI: 10.12913/22998624/59086. 9. Gogolin, A., Wasilewski, M., Ligus, G.; Wojciechowski, S.; Gapinski, B.; Krolczyk, J.; Zajac, D.; Krolczyk, G.: Influence of geometry and surface morphology of the U-tube on the fluid flow in the range of various velocities, Measurement, No.164, 2020, art. no.108094, DOI: 10.1016/j.measurement.2020.108094. 10. 10. Varga, G., Ferencsik, V.: Analysis of surface topography of diamond burnished aluminium alloy components, Lecture notes in mechanical engineering, 2017, pp.143-154. 11. Molnar, V.: Tribology and Topography of Hard Machined Surfaces, Rezanie i instrumenty $\mathrm{v}$ tekhnologicheskih sistemah, No. 94, 2021, pp.49-59. 12. Gadelmawlaa, E.S., Kourab, M.M., Maksoucf, T.M.A., Elewaa, I.M., Solimand, H.H.: Roughness parameters, J. of Mat. Proc. Techn., Vol. 123, 2002, pp.133-145. 13. ISO 25178-2:2012 Geometrical product specifications (GPS) Surface texture: Areal - Part 2: Terms, definitions and surface texture parameters. 2012. 14. Stout, K., Blunt, L.: Three-dimensional Surface, Topography. 2 ed. London: Penton Press, 2000. 15. Bitelli, G., Simone, A., Girardi, F., Lantieri, C.: Laser Scanning on Road Pavements: A New Approach for Characterizing Surface Texture, Sensors, No.12, 2012, pp.9110-9128, DOI: 10.3390/s120709110.

\title{
Віктор Мольнар, Мішкольц, Угорщина
}

\section{ЗНОСОСТІЙКІСТЬ ПОВЕРХОНЬ ЗАГАРТОВАНИХ ДЕТАЛЕЙ ПІСЛЯ ОБРОБКИ ТОЧІННЯМ}

\begin{abstract}
Анотація. Обробка загартованих матеріалів є складним завданням. Можливе як звичайне шліфування, так і використання одноточкових інструментів. Жорстке точіння - хороший вибір для обробки загартованих поверхонь за рахунок відносної швидкості знімання матеріалу $i$ може забезпечити ефективну процедуру. Однак токарна обробка твердих матеріалів вимагає верстат з жорсткою структурою та інструменти з надтвердих матеріалів для досягнення очікуваної точності та якості поверхні. Жорстке точіння призводить до періодичного рельєфу поверхні. Через складну систему вимог до робочих поверхонь, топографія $i$, отюе, характеристика шорсткості поверхні стали пріоритетними темами при обробці. Зносостійкість - це трибологічні властивості поверхонь. Існує безліч параметрів шорсткості, які покликані надати інформацію про зносостійкість поверхні. У иььому дослідженні демонструються результати експериментів із твердим точіння. Технологічні параметри (швидкість різання, подача, глибина різання) змінювалися. Відповідно до рекомендацій виробника інструменту були застосовані найнижчі та найвищі значення цих даних, $i$ було проведено планування експерименту, в результаті якого було отримано 8 налаштувань. Новизна експериментів у тому, що з аналізу зносостійкості одночасно враховувалися більше одного параметра шорсткості, а експерименти проводилися для усього діапазону технологічних параметрів. Експерименти по жорсткому точінню проводилися для 8 установок з варіюванням значень технологічних параметрів швидкості різання, глибини різання та подачі. Були проаналізовані $3 D$ параметри шорсткості поверхні $S_{p k}, S_{s k}$ та $S_{k u}$. Зміна глибини різання та швидкості різання не впливає на аналізовані значення. Сдина чітка констатація експериментів - подача впливає на аналізовані параметри шорсткості. Коли застосовувалася нижча подача (0,05 мм/об), зносостійкість була явно кращою, ніж у разі більш високої (0,3 м/об) подачі. Усі три параметри шорсткості підтверджують це твердження. Результати можуть надати корисну інформацію для дослідження трибологічних характеристик оброблених поверхонь.
\end{abstract}

Ключові слова: жорстке точіння; зносостійкість; 3D шорсткість поверхні. 